Article

\title{
Territorial Management and Governance, Regional Public Policies and their Relationship with Tourism. A Case Study of the Azores Autonomous Region
}

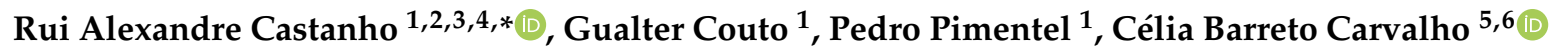 \\ and Áurea Sousa ${ }^{7}$ \\ 1 School of Business and Economics and CEEAplA, University of Azores, 9500-321 Ponta Delgada, Portugal; \\ gualter.mm.couto@uac.pt (G.C.); pedro.ms.pimentel@uac.pt (P.P.) \\ 2 Faculty of Applied Sciences, WSB University in Dąbrowa Górnicza, 41-300 Dąbrowa Górnicza, Poland \\ 3 VALORIZA-Research Centre for Endogenous Resource Valorization, 7300 Portalegre, Portugal \\ 4 CITUR-Madeira-Centre for Tourism Research, Development and Innovation, \\ 9000-082 Funchal-Madeira, Portugal \\ 5 Faculty of Social and Human Sciences, University of Azores, 9500-321 Ponta Delgada, Portugal; \\ celia.mo.carvalho@uac.pt \\ 6 CINEICC-Cognitive and Behavioral Centre for Research and Intervention, Faculty of Psychology and \\ Educational Sciences, University of Coimbra, 3000-115 Coimbra, Portugal \\ 7 Faculty of Sciences and Technology and CEEAplA, University of Azores, 9500-321 Ponta Delgada, Portugal; \\ aurea.st.sousa@uac.pt \\ * Correspondence: acastanho@wsb.edu.pl
}

Received: 29 June 2020; Accepted: 21 July 2020; Published: 28 July 2020

check for updates

\begin{abstract}
Bearing in mind the growth in regions with socio-economic bases dependent on tourism, studies that analyze spatial planning processes, regional public policies, and their relationship with tourism activities are essential to achieve the so-desired sustainable territorial development. Through case study research methods, territorial impact analysis, and questionnaires to explore the public perceptions, it was possible to design and implement a study regarding this specific regional governance theme on the Azores Autonomous Region (AAR). The research allowed us to learn that the most affected activities by public territorial policies in the AAR from the respondents' perspective were accommodation (54.7\%) and nature (51.9\%). Conversely, the less affected were culture (15.1\%) and rental/hire services (17.9). Furthermore, it was possible to identify two factors that rule public policies on the growth and development of the Azores: (i) impact in the natural landscape and (ii) suitable production factors.
\end{abstract}

Keywords: Azores islands; public policies; regional studies; socio-economy; sustainable development; sustainable tourism; territorial governance; urban and rural planning

\section{Introduction}

Sustainable development and growth are undoubtedly one of the main concerns and objectives of regional territories today [1-4]. This type of growth is no longer just a wish but a territorial need to improve the quality of life of the populations and also to guarantee a future for coming generations [5-13].

In this regard, the territorial planning strategies are an essential instrument for assigning pre-conditions of resources to the inhabitants [5]. Such planning tools promote prosperity for future living in that region, fostering the decline of social unbalances and spatial disparities and being an incentive mechanism for sustainable development [2-5]. 
Considering this type of growth, and particularly for territories with socio-economic bases inevitably linked to tourism, regional planning policies can present impacts of a grander scale than areas where the socio-economic basis does not depend solely on tourism [14,15].

Thus, studies that cross and analyze spatial planning, strategic planning, other planning related processes, and their relationship with tourism activities are seen as essential to the sustainable development of these territories $[15,16]$. Based on this, and considering the characteristics presented of isolated low-density territory by the Azores Autonomous Region (AAR), the following research question is raised: "What is the perception of tourists and locals in the Azores Region about the relationship and impacts between public policies, territorial planning, and the influence on regional tourism?"

This article is one of the first to explore the interconnectivity between regional public policies and territorial governance with tourism in the Azores Archipelago, considering the tourists' and residents' perceptions.

Thereby, this research addresses a critical gap in the empirical literature. It has focused mainly on the analysis of the relationships and impacts considering the literature review without assessing public perceptions. The study fills this empirical gap and investigates further than the theoretical sphere by examining the opinions of the ones that are the most affected by such regional public policies.

Contextually, to provide an answer to the research question, we applied testing tools regarding the perception of Azores residents and tourists on the regional territorial policies and their management.

\section{Sustainable Development, Tourism, and Insular Regions}

Sustainable development can be described as development that meets the needs of the present without threatening the ability of future generations to meet their own needs [2,3,5-13].

In fact, multiple criteria characterize this concept [17]. Within the several fields of action of sustainable development, one of the most relevant is the theme of planning and strategic planning [8-11]. If we center on those regional planning strategies, overall, they intend to improve urban and rural quality of life through the responsible use of the land and the preservation of harmony among the human-made built environment and nature [18-21].

From a growth perspective, sustainable development is consequently connected to and overlaps with sustained economic growth, social equality and inclusion, and environmental conservation and protection [22]. It also requires strong political commitment, stakeholders' active involvement, and public participation [23]. Territorial planning is consequently a tool for the development of urban and rural areas, designed to improve regional and local economies, foster social cohesion and growth, as well as to implement a more environmentally conscious (eco-friendly), inclusive, and safer territory [2].

Thereby, three pillars need to be discussed:

(i) Economic - sustainability requires an economic system that matches the interests of its citizens, offers enough employment, and can rejuvenate its population to address these services in the long term $[24,25]$. To meet those requirements, the competitiveness of the economic system must be part of the concept of sustainability [25]. It can be further extrapolated ahead of this description to include regional and local economic development models, land use and land cover, and real estate markets, among others [26-28].

(ii) Social-in general, this pillar refers to public policies that undertake social challenges. Such social problems are related to our collective well-being and prosperity-i.e., healthcare, education, housing, and employment, among many other factors [29]. As part of the social pillar, the institutional dimension must also be addressed. According to Jörg Spangenberg [25]: "Institutions are the success of social interactions, along with established rules over society, by decision-making processes and their tools to apply such policies. Thus, the institutional dimension includes groups from civil society and the policy-makers, from the administrative system, and technicians." Therefore, from a sustainable 
development perspective, we should consider public participation, equality of opportunities, no social discrimination, and strong political commitment and transparency.

(iii) Environmental - the environmental dimension is described as the sum of all bio-geological processes along with their elements. Therefore, it demands the conservation and preservation of ecological systems as the natural basis for supporting human society [25,30]. Through well-designed and executed planning strategies, the integration and cooperation between societies and the environment may create several benefits for cities and territories in different contexts. Such synergies support green areas with ecological and cultural heritage value, protecting biodiversity and preventing the formation of heat islands in urban territories, among several other benefits [11,31]. It should also consider the estrangements arising from disparities in planning intentions, such as differing interests of stakeholders, or issues related to the planning of waste management, among many other challenges in rural and urban territories. In fact, those planning problems will be used as incentives to promote economic performance, social equity, and environmental efficiency, instead of sustainable development barriers.

Based on the pillars mentioned above, it is possible to recognize the ample scope of sustainable development and its interaction with activities and disciplines such as tourism.

According to Hui and Bao [32]: "( . . ) Nature-based tourism also enables a certain degree of urbanization that may lead to further resource conflicts, which, if not promptly resolved, are likely to sow the seeds of socio-cultural problems". Further, the antagonism between tradition and modernity, which can be understood as a socio-cultural collision, has been marked out as one of the most generalized and critical kinds of dispute in today's urbanized world [33,34].

Thus, policymakers and the main actors involved in the encouragement of sustainable development should also recognize the consequences of the economic, environmental, social, and cultural elements involved [35]. In this sense, many scientists refer to the importance of integrated sustainable development, as is the case of Rodríguez-Serrano et al. [36], who affirm: “(...) The growing acceptance that decision-making practices must also consider socio-cultural issues, which ought to be monitored throughout the entire supply chain, has led to the emergence of methodological frameworks for integrated sustainability assessment, whose outputs should simultaneously capture the economic, environmental, and social impacts." Consequently, the planning strategies, methods, and approaches for sustainable tourism, which also means planning for sustainable development, require the use of this type of instruments [37].

\section{Peripheral and Insular Areas}

It is recognized that agriculture plays an essential role in less competitive territories and regions. This problem is even more apparent in Southern European countries [14]. These countries' insular territories are not an exception. Thereby, the archipelagos of Canary Islands, Madeira, Cabo Verde, or the Azores are just some examples. In fact, this issue earns additional importance in those ultra-peripheral regions [14]. With regard to these singular areas, Labrianidis and Thanassis [38] describe: “( ... Entrepreneurship, associated with small- and medium-sized businesses, is one way to achieve sustainable development in the countries of Southern Europe, once it allows increasing employment and incoming investments."

Besides, it should be highlighted that frequently these territories show many problems related to economic decline, high unemployment rates, emigration flux, and adverse impacts resulting from agricultural land re-conversion, as well as with the associated cultural identity loss [39]. Tourism and tourism-related activities can add considerably to rural areas and low-density regions [4].

Bearing in mind prior studies, as is the example of Williams [40], it is possible to understand that employment in tourism had a meaningful involvement in improving national economic growth; besides, it has also been a catalyst for regional economic transformations. Several types of research conducted in low-density, rural, and peripheral territories-see Fleischer and Felsenstein [41] or Mazumder et al., [42]; all show that tourist spending creates more employment and profit than any other economic sector. Also, it creates and sustains jobs in other economic sectors that support visitor and tourism businesses. Nevertheless, to create sustainable development strategies based on tourism, 
rural and peripheral areas should offer some pre-required features-i.e., regional and local know-how and quality resources, among many others, in order to benefit from windows of opportunity created in these high unemployment territories [41].

According to Reeder and Brown [43]: "Tourism can be one activity capable of contributing to the revitalization of local economies, diversification of activities that are tributaries, development of other economic sectors (by the multiplier effect), creation and qualification of employment, income generation, improvement of transport infrastructure, of services (which also benefit the local society), and the creation of local government revenue." Nevertheless, to develop a prosperous strategy, in the first place, a policy centering on sustainable development should be designed premised on significant investments in infrastructure and services-i.e., accessibility and connectivity, movement between cities and regions, and power networks, the creation of human assets, among many other critical factors [12,13,44-46]. Such factors are essential to attracting investors and investment and inherent to sustainable territorial development.

Considering the above-mentioned, tourism should be classified as an isolated element of a wider sustainable development program but indissociable from the spheres. Besides, it is essential to stretch cooperation between the public sector, private sector, communities, and civil society, intending to guarantee that the purposes of its investment policies are obtained [47].

\section{Spatial Planning of Tourism and Sustainability in the Azores Archipelago}

In 2008, the Regional Government announced the Spatial Plan of Tourism of the Azores' Autonomous Region (POTRAA) [48]. It was defined as the fundamental mechanism for achieving the sustainable development of the region's tourism sector. In effect, it was also an instrument to guide the various economic actors and discipline the administrative action, establishing the strategic tourism products and the evolution of the tourism supply until 2015. Nevertheless, it is still in effect, although it has been partially suspended and under deep revision.

For some years, POTRAA was the central instrument of the Azores tourism strategy, despite being a territory management instrument. The way it was developed allowed the concentration of much more than spatial management mechanisms, stretching its reach to all the region's tourism strategy. Knowing that the image of the Azores as a destination was strongly related to nature and sustainability, the plan established six Strategic Development Guidelines: (i) Reinforcement and deepening of technical, organizational, and regulatory conditions to support tourism development; (ii) Support for the improvement of infrastructure and complementary/support services of the tourism sector, to the internal and external accessibilities and the tourism signage; (iii) Support for the development, qualification, and diversification of the regional tourism supply; (iv) The stimulus of the tourist demand and the external awareness of the regional tourism; (v) Support for specific actions regarding the spatial planning of tourism; and (vi) Promoting the implementation and monitoring of the plan.

POTRAA established a Territorial Organization Model, with cartographic support, beyond suggesting a model for the distribution of the tourism supply in each island and a coordinated approach with municipal territorial management instruments. The plan recommended the creation of Places with Specific Tourism Vocation, according to their natural, scenic, and urban characteristics, in addition to particular attention to more fragile ecologic areas, limiting their use for tourism.

The document also identified the main tourism products for each island and strategically established a specific core tourism product and some other complementary features for each of the nine islands. That was done to serve as a guideline to the islands' tourism development, mobilize differentiating elements, and establish a coherent strategy for preserving each island's environment and cultural identity. These products and resources should influence the regional tourism strategy and the local tourism development according to the islands' peculiarities and specific social, economic, environmental, and cultural contexts. That is further detailed in Chapter 3; nevertheless, it is evident that POTRAA's (2008) fundamental principles were already nurturing exciting elements for developing the slow adventure concept, including nature, local culture, and sustainability. 
As mentioned, POTRAA is under deep revision, and it is expected that by the end of 2021, a new version will be available. Some of the goals have the potential to contribute to the development of slow adventure in the Azores: redefining the organization of the Azores as a tourism destination, following sustainable and integrated development of the tourism activity; improving the quality of the regional tourism supply; contributing to the increase in tourism demand in the region, the average length of stay, and tourism revenues; distributing tourism flows more equitably throughout the nine islands and the year to soften the adverse effects of tourism's seasonality; preserving the natural and cultural heritage; identifying, on each island, the areas associated with the different tourism activities and the establishment of new tourism enterprises, indicating the respective typology and the carrying capacity of each zone; and preventing the degradation of the destination through a sustainable tourism policy.

Silva and Almeida [49] claim that: "regions such as the Azores have great potential for the development of nature and adventure tourism products, but, due to their early stage of development as destinations and the limitations in their carrying capacity, it is necessary to guarantee a sustainable tourism development model." This model should focus on the endogenous resources to achieve the diversification of tourism products, satisfy visitors' expectations [50], and minimize the impact of tourism activities. Therefore, careful destination planning and tourism development management seem critical to avoid some of the impacts associated with the maturity and saturation stages of a destination lifecycle, such as polluted environments and landscapes, the decay of heritage, water pollution, and erosion and traffic congestion. Again, slow adventure perfectly fits this scenario and can even be a way to achieve sustainable and well-balanced tourism development [51,52].

Sustainability in the Azores is taken very seriously by the local authorities, and it is considered a critical factor for the region's tourism sector [53-55]. In 2007, National Geographic Traveller elected the Azores as the second-best islands for sustainable tourism. The report included very relevant appraisals of the natural environment and cultural diversity. However, it was also pinpointed that inappropriate development was beginning to appear.

For instance, on the one hand, Silva and Almeida [18] note that individuals and companies that offer canyoning activities in the Azores are aware that the environment is an indispensable asset for the quality of their product and, therefore, actively contribute to its conservation. For tourism activities and companies in the Azores, see Couto et al. [56].

On the other hand, the recent tourism outburst brings several problems related to hiking trail upkeep, and traffic blockage has developed in a few famous local attractions. Whale watching, one of the most meaningful tourism activities in the Archipelago, has also suffered significant setbacks. In 2009, oversight efforts on whale watching activities were reinforced due to some non-compliance with local regulations. Back in 2010, the Regional Government established additional limitations on whale watching activities and limited access to licenses due to increasing pressure on whales, dolphins, and their calves. This whole situation is one of the main concerns that is being addressed in POTRAA's revision since it is critical to maintaining sustainable tourism development in the region.

The Azores has been granted several awards and international appraisals regarding sustainable development and sustainable tourism. Some of these awards come from prestigious international institutions, such as UNESCO, National Geographic Traveller, QualityCoast, and Green Destinations (Table 1). Very recently, in March 2018, the Azores were awarded the Best Sustainable Destination of the Atlantic award, which is a significant landmark for the regional tourism sector $[57,58]$. 
Table 1. Azores sustainability and sustainable tourism awards (Source: [57]).

\begin{tabular}{|c|c|c|c|}
\hline Award & Organization & Comments & Year \\
\hline $\begin{array}{l}\text { Top } 10 \text { Most Sustainable } \\
\text { World Destinations }\end{array}$ & Green Destinations & Best of the Atlantic & 2018 \\
\hline $\begin{array}{l}\text { Top } 100 \text { Most Sustainable } \\
\text { World Destinations }\end{array}$ & Green Destinations & First place in 2014 , with 8.9 points out of 10 & $\begin{array}{l}2018 \\
2017 \\
2016 \\
2014\end{array}$ \\
\hline QualityCoast Platinum Award & $\begin{array}{l}\text { QualityCoast-Coastal } \\
\text { and Marine Union of the } \\
\text { European Union }\end{array}$ & $\begin{array}{l}\text { 2017: On par with two other Dutch } \\
\text { destinations-Goedereede } \\
\text { and Westvoorne } \\
\text { 2014-2016: First and, at the time, an } \\
\text { only destination with this award }\end{array}$ & $\begin{array}{c}2017 \\
2014-2016\end{array}$ \\
\hline QualityCoast Gold Award & $\begin{array}{l}\text { QualityCoast-Coastal } \\
\text { and Marine Union of the } \\
\text { European Union }\end{array}$ & Best Quality Coastal Destination in Europe & 2013 \\
\hline $\begin{array}{c}\text { Best of the Best- Nature } \\
\text { Award }\end{array}$ & European Commission & $\begin{array}{l}\text { Granted to Project "Life Priolo", which was } \\
\text { developed between } 2003 \text { and 2008, focused } \\
\text { on the protection and restoring of the risk } \\
\text { vegetation of the laurel forest of the Azores }\end{array}$ & 2010 \\
\hline $\begin{array}{l}\text { Second-Best Islands in the } \\
\text { World for Sustainable Tourism }\end{array}$ & $\begin{array}{l}\text { National Geographic } \\
\text { Traveler }\end{array}$ & - & 2010 \\
\hline Ospar Convention & OSPAR Commission & $\begin{array}{l}12 \text { locations identified for the } \\
\text { protection of the maritime } \\
\text { environment of the Northeast Atlantic }\end{array}$ & 2010 \\
\hline Biosphere Reserves & UNESCO & $\begin{array}{ll}\text { - } & \text { Island of Flores } \\
\text { - } & \text { Island of Graciosa } \\
\text { - } & \text { Island of Corvo }\end{array}$ & $\begin{array}{l}2007 \\
2007 \\
2009\end{array}$ \\
\hline Natura Network 2000 & European Commission & $\begin{array}{l}\text { - } 23 \text { Special Preservation Areas } \\
\text { - } \quad 15 \text { Special Protection Areas } \\
\text { - } 2 \text { Important Locations of } \\
\text { the Community }\end{array}$ & 1989 \\
\hline UNESCO World Heritage & UNESCO & $\begin{array}{l}\text { - The landscape of Pico Island } \\
\text { Vineyard Culture } \\
\text { - Historical Centre of Angra do } \\
\text { Heroísmo }\end{array}$ & $\begin{array}{l}1983 \\
2004\end{array}$ \\
\hline
\end{tabular}

Nevertheless, the Regional Government keeps raising the bar and, in December 2017, announced the start of a process that aims for the Azores to achieve certification as a Sustainable Destination according to the criteria established by the GSTC — Global Council for Sustainable Tourism. That is a very ambitious and demanding goal, especially when tourism is expected to keep growing at a quick pace in the next few years. However, it can signify a new competitive advantage and an element of value creation, and in 2020 Azores received this award.

\section{Material and Methods}

Considering the aim of the investigation, it required the use of several methods throughout the research, including direct and indirect research methods and tools. 
In this regard, the methodological approach was divided into four main phases ending in the Relationship between Territorial Management and Governance, Regional Public Policies and Their Impact on Tourism in the Azores (Figure 1).

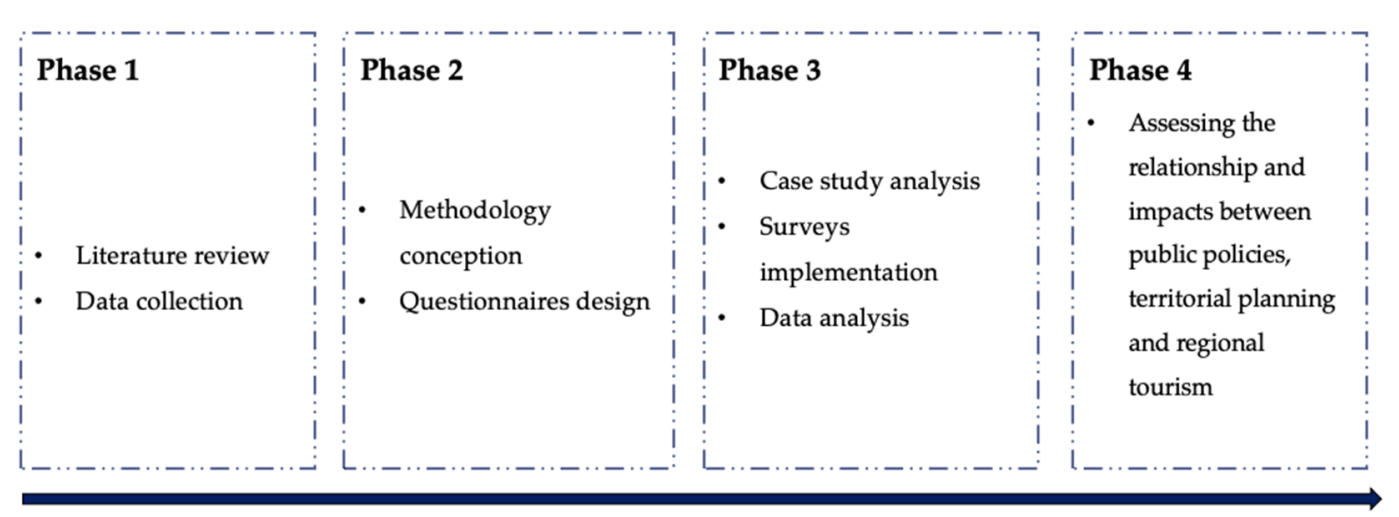

Figure 1. Methodological approach.

Using a case study analysis method, it was possible to collect a considerable amount of data, gaining an in-depth understanding of the main issues about land use planning and its influence on regional tourism. The authors consider the case study analysis method put forward by Robert Yin [59] as a powerful tool to analyze and obtain information for similar examples-it extracts the lessons learned and applies them to this specific case study. Following the author Mark Francis [60], "A case study is a well-documented and systematic examination of the process, decision-making, and outcomes of a project undertaken to inform future practice, policy, theory, and education."

Therefore, a similar study carried by Castanho et al. [61] in Madeira's insular region using the same methodology was used as a case study reference as well as a starting point for this work.

Considering several sources of information-i.e., literature review, technical and scientific articles, dimensioning projects, regional proposals, consultation of space users, site analysis-used throughout the investigation, it was possible to carry out the intended research.

\section{Questionnaires and Results}

The results listed below are provided by direct analysis-through the implemented surveys, from April to May of 2020; and by crossing the existing literature review.

The questionnaire starts by collecting the sample profile of the participants (Table 2). Of the total of 106 participants in the study, $92.5 \%$ are Azores residents, and the remaining $7.5 \%$ are non-residents of Azores. The participants were divided into three age groups: $18-35 ; 36-50$; and over 50 years $(+50)$. The most representative group was $18-35$ years old $(57.5 \%)$, followed by $36-50(22.6 \%)$, with the least representative age group being the ones over $50(19.8 \%)$. Concerning gender, $63.2 \%$ of the participants were female and $36.8 \%$ male. The participants' fields of expertise were more representative than Social Sciences $(17.9 \%)$ and Others $(23.8 \%)$.

From the survey participants' perceptions, it was possible to understand which are the most representative tourist age groups in the Azores (Table 3), in the present moment (question A), and also considering the last few decades (question B). In this regard, in the present moment, the most representative age group of tourists in the Azores was 36-50 years old (51.9\%), followed by the age group of over $50(34.0 \%)$; the least representative was the age group of $18-35$ years $(10.4 \%)$. Considering the last few decades, the most representative age group of tourist in the Azores was over $50(43.4 \%)$, followed closely in numbers by the age group 36-50 (40.6\%), and with a small percentage representing the ages 18-35 (3.8\%). In question B, the considerable number of "Do not know/Do not answer" should also be highlighted with $12.3 \%$. 
Table 2. Sociodemographic characteristics of the participants.

\begin{tabular}{|c|c|c|c|}
\hline Variables & $\%$ & Variables & $\%$ \\
\hline \multirow{2}{*}{\multicolumn{2}{|c|}{ Gender }} & Field of expertise & \\
\hline & & Economic Sciences & $11.9 \%$ \\
\hline Male & $36.8 \%$ & Education & $10.4 \%$ \\
\hline Female & $63.2 \%$ & Engineering & $2.9 \%$ \\
\hline \multicolumn{2}{|c|}{ Age Group } & $\begin{array}{l}\text { Management and } \\
\text { Administration }\end{array}$ & $16.4 \%$ \\
\hline $18-35$ & $57.5 \%$ & Medical Sciences and Biology & $5.8 \%$ \\
\hline $36-50$ & $22.6 \%$ & Planning & $4.4 \%$ \\
\hline+50 & $19.8 \%$ & Social Sciences & $17.9 \%$ \\
\hline \multicolumn{2}{|c|}{ Resident of the Azores } & Tourism & $5.9 \%$ \\
\hline Yes & $92.5 \%$ & Others & $23.8 \%$ \\
\hline No & $7.5 \%$ & & \\
\hline
\end{tabular}

Table 3. Most representative tourist age groups in Azores in the participants' opinion.

\begin{tabular}{ccccc}
\hline \multirow{2}{*}{ Questions * $^{*}$} & \multicolumn{3}{c}{ Answers \% } \\
\cline { 2 - 5 } & $\mathbf{1 8 - 3 5}$ & $\mathbf{3 6 - 5 0}$ & $\mathbf{+ 5 0}$ & Do not know / Do not answer \\
\hline $\mathrm{A}$ & $10.4 \%$ & $\mathbf{5 1 . 9 \%}$ & $34.0 \%$ & $3.8 \%$ \\
$\mathrm{~B}$ & $3.8 \%$ & $40.6 \%$ & $\mathbf{4 3 . 4 \%}$ & $12.3 \%$ \\
\hline
\end{tabular}

The highest values found are in bold. *(A) In your opinion, what is the most representative/predominant age group of actual tourists in the Azores?; (B) Considering the last few decades, what was the most representative/predominant age group for tourists in the Azores?

Table 4 shows us the results of the closed-ended questions. Overall, in all five closed-ended questions, the highest percentages of answers were found in the categories "Yes" and "Positives"; however, there was some variance between questions. Questions a and b clearly show a "Yes" (with more than $96 \%$ of the total of answers). When the participants were asked if they believe that the changes suffered in the AAR landscape have an impact on tourism (question c), even if $85.8 \%$ said "Yes", 9.4\% said "No". A similar scenario occurred in question d, with $84.9 \%$ of the answers saying "Yes" and only $2.8 \%$ saying "No." Nevertheless, in question (d) there is an increase in the percentage of "Do not know / Do not answer" (12.3\%), revealing some lack of knowledge of the topic by the participants.

Table 4. Closed-ended questions.

\begin{tabular}{cccc}
\hline \multirow{2}{*}{ Questions * $^{*}$} & \multicolumn{3}{c}{ Answers \% } \\
\cline { 2 - 4 } & Yes & No & Do not know/Do not answer \\
\hline a & $\mathbf{9 9 . 1 \%}$ & $0.9 \%$ & $0.0 \%$ \\
b & $\mathbf{9 6 . 2 \%}$ & $0.9 \%$ & $2.8 \%$ \\
c & $\mathbf{8 5 . 8 \%}$ & $9.4 \%$ & $4.7 \%$ \\
d & $\mathbf{8 4 . 9 \%}$ & $2.8 \%$ & $12.3 \%$ \\
\hline \multirow{2}{*}{ Question ** } & \multicolumn{2}{c}{ Answers \% } \\
\cline { 2 - 4 } & Positives & Negatives & Do not know / Do not answer \\
\hline e & $\mathbf{4 5 . 3 \%}$ & $36.8 \%$ & $17.9 \%$ \\
\hline
\end{tabular}

The highest values found are in bold. * (a) Do you believe that in the last decade tourism in the Azores has increased?; (b) From a comparative point of view, within the last decade, have you noticed an improvement in the financial results that tourism has brought to the region?; (c) Do you believe that the changes suffered by the AAR landscape have an impact on tourism?; (d) Do you believe that spatial planning and territorial strategies have a direct impact on tourism? ${ }^{* *}$ (e) Based on the assumption that there are impacts related to tourism and its relationship with the AAR landscape, how do you classify these impacts? 
From this set of closed-ended questions, the more divided results were found in question e-Based on the assumption that there are impacts related to tourism and its relationship with the Azores landscape, how do you classify these impacts? - where the participants were asked to answers if those impacts are "Positive", "Negative", or even if they "Do not know/Do not answer". Therefore, for positive impacts the result was $45.3 \%$, for negative impacts-36.8\%, and $17.9 \%$ of them selected the option "Do not know/Do not answer". Therefore, it is possible to verify the divided opinion between positive impacts and negative.

The questionnaire also presents a section concerning the participants' agreement levels (Table 5). Thus, through a five-point Likert-scale assessment method, the respondents were asked to state their agreement with five sentences, where 1 represents total disagreement and 5 total agreement. Regarding the sentence (i): The type of tourism the Azores Autonomous Region receives is the desired for the regional socio-economic base; the median value was 4 , and the most verified agreement level was $3(41.9 \%)$, followed closely by the agreement level $4(39.0 \%)$, and the third most selected agreement level was $5(12.4 \%)$. Therefore, a clear tendency is shown of agreement with this sentence (sentence i). Similar results were found for sentences ii, iii, and iv (median values, respectively, 3.5, 3, and 3). However, for sentence (ii) - The growth and development of the Azores Autonomous Region are sustainable-an even more positive tendency is possible to evidence as the most selected agreement level was $4(40.6 \%)$, and the median value was 3.5 .

Table 5. Likert scale questions.

\begin{tabular}{cccccc}
\hline \multirow{2}{*}{ Sentences * } & \multicolumn{5}{c}{ Level of Agreement ** \% } \\
\cline { 2 - 6 } & $\mathbf{1}$ & $\mathbf{2}$ & $\mathbf{3}$ & $\mathbf{4}$ & $\mathbf{5}$ \\
\hline i & $0.0 \%$ & $6.7 \%$ & $\mathbf{4 1 . 9 \%}$ & $39.0 \%$ & $12.4 \%$ \\
ii & $0.0 \%$ & $12.3 \%$ & $37.7 \%$ & $\mathbf{4 0 . 6} \%$ & $9.4 \%$ \\
iii & $0.0 \%$ & $11.3 \%$ & $\mathbf{4 5 . 3} \%$ & $38.7 \%$ & $4.7 \%$ \\
iv & $2.8 \%$ & $9.4 \%$ & $\mathbf{4 2 . 5 \%}$ & $39.6 \%$ & $5.7 \%$ \\
v & $1.9 \%$ & $17.0 \%$ & $\mathbf{3 7 . 7} \%$ & $31.1 \%$ & $12.3 \%$ \\
\hline
\end{tabular}

The highest values found are in bold. * (i) The type of tourism the Azores receives is the desired for the regional socio-economic base.; (ii) The growth and development of the Azores are sustainable.; (iii) The territorial planning strategies aimed at the AAR, and the projects that resulted from them, in the last decades, were adequate.; (iv) The spatial planning and territorial strategies carried out in the AAR in the last decades represent positive impacts on the residents' quality of life.; (v) In the last decades, the natural landscape of the AAR has undergone profound changes through policies and strategies of spatial planning. ${ }^{* *} 1$-Totally disagree;5-Totally agree.

Another sentence showing a positive tendency is sentence (v): In the last decades, the natural landscape of the AAR has undergone profound changes through policies and strategies of Spatial Planning (median value $=3$ ); however, there was a noticeable 17.0\% in agreement level 2 (indicator in the opposite way of the positive tendency).

Furthermore, the values of Spearman's rank correlation coefficient was calculated between pairs of items (sentences) i, ii, iii, iv, and v (Table 6).

Table 6. Correlation matrix-Spearman's rank correlation coefficient values *.

\begin{tabular}{|c|c|c|c|c|}
\hline & ii & iii & iv & $\mathbf{v}$ \\
\hline $\mathrm{i}$ & $0.512 * *$ & $0.412 * *$ & $0.444^{* *}$ & -0.110 \\
\hline ii & 1.000 & $0.521 * *$ & $0.545 * *$ & -0.025 \\
\hline iii & & 1.000 & $0.555 * *$ & 0.049 \\
\hline iv & & & 1.000 & 0.137 \\
\hline $\mathrm{v}$ & & & & 1.000 \\
\hline
\end{tabular}


Table 6 shows that item $\mathrm{v}$ (sentence $\mathrm{v}$ ) is the only one that does not show statistically significant correlations with the other items in the table.

Moreover, ascendant hierarchical cluster analysis (AHCA) for items i, ii, iii, iv, and v was carried out based on the affinity coefficient (e.g., [62]), combined with five aggregation criteria: two classical, namely, single-linkage (SL) and complete-linkage (CL), and three probabilistic, within the scope of the VL Methodology (V for validity, L for linkage), namely, AVL, AV1, and AVB (e.g., [62-66]). The choice of the most significant partition was based on the global statistics of levels, STAT (e.g., [62,63]). Table 7 contains the values of the affinity coefficient between the pairs of the analyzed items.

Table 7. Matrix with the values of the affinity coefficient between pairs of items.

\begin{tabular}{cccccc}
\hline & i & ii & iii & iv & v \\
\hline i & 1.000000 & 0.993178 & 0.992565 & 0.991502 & 0.980975 \\
\hline ii & & 1.000000 & 0.993654 & 0.993040 & 0.981013 \\
\hline iii & & & 1.000000 & 0.993396 & 0.983799 \\
\hline iv & & & 1.000000 & 0.982136 \\
\hline v & & & & & 1.000000 \\
\hline
\end{tabular}

According to the value (2.558) of STAT, the best partition is a partition into two clusters: Cluster 1: $\{\mathrm{i}, \mathrm{ii}, \mathrm{iii}, \mathrm{iv}\}$; Cluster 2: $\{\mathrm{v}\}$.

Figure 2 shows the dendrogram obtained with the SL, CL, AVL, AV1, and AVB methods, where the great proximity between items ii and iii is of note.

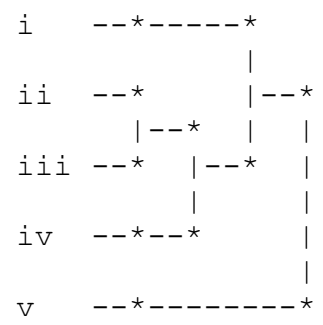

Figure 2. Dendrogram provided by several methods: SL, CL, AVL, AVB, and AV1.

The participants were also asked about the activities most affected by the potential impacts of territorial planning strategies on tourism (Table 8). The most affected activities by these public policies from the respondents' perspective were accommodation ( $54.7 \%$ of the participants), followed by nature $(51.9 \%)$. In contrast, the least affected according to the collected perceptions were culture $(15.1 \%)$ and rental/hire services $(17.9 \%)$.

Table 8. Selection question *.

\begin{tabular}{cc}
\hline Activities & Answers (\%) \\
\hline Accommodation & $\mathbf{5 4 . 7 \%}$ \\
\hline Culture & $15.1 \%$ \\
\hline Nature & $\mathbf{5 1 . 9 \%}$ \\
\hline Rental/hire services & $17.9 \%$ \\
\hline Restoration & $38.7 \%$
\end{tabular}

The highest values found are in bold. * Question: If there are impacts related to territorial planning strategies on tourism, which activities are most affected? 
Besides, an open question regarding "what measures should be taken to achieve sustained regional growth if there are negative impacts of spatial planning strategies on tourism" was also part of the questionnaire. This question explores the perception of the participants regarding potential measures towards sustainable regional growth. Therefore, and considering it was an open question, the respondents' answers were grouped into six main measures: (i) accessibility and connectivity; (ii) better management of regional tourism; (iii) better public policies; (iv) nature protection and conservation; (v) protecting the local population instead of foreign visitors/tourists; and (vi) regional strategic planning.

\section{Discussions and Conclusions}

The close-ended questions show respondents' knowledge regarding the last decades in Azores tourism dynamics, with special insight that spatial planning and territorial strategies have had a positive direct impact on tourism.

Recall that the Azores are in an early stage regarding tourism development with most touristic infrastructures, including natural spots and accommodation, lacking conditions to meet tourist demands.

From the very beginning, spatial planning and territorial strategies have considered natural sustainability, forcing the bubbling economic players in the tourism sector to discipline their investments and simultaneously creating conditions to support increased tourism. Not all were appropriate, although the bottom line is that positive impacts on Azores tourism came from changes in the landscape. In fact, long-term success depends on future spatial planning and territorial strategies [67-69].

Regarding this issue, it is not surprising that the responses to questions regard accommodation and nature as the most affected by public policies. On the one hand, much public investment was undertaken in communications infrastructures (roads, parking lots, seaports, airports, hospitals, etc.) using EU structural funds [68]. On the other hand, several subsidies programs with EU funds push hard private investments in accommodation units and touristic activities $[66,68]$. Unfortunately, investments in culture, rental, and restoration activities have not received the same attention from subsidies programs in the last decades.

Regarding the Likert scale questions, we may conclude that, from the respondents' perspective, the growth and development of the Azores are sustainable and focusing on foreign high market segments. Moreover, over $50 \%$ disagree or do not take a clear position on adequate territorial planning strategies and projects and increase residents' living standards. Early-stage Azores tourism could justify why most of the benefits from tourism did not reach population income, as they would expect. Unemployment has decreased, but low wages remain mainly for employees with no specialist skills [68]. In this ramp-up phase, investors are debating ways to recover their investments or reinvest to expand capacity.

Less than $45 \%$ agree that the natural landscape suffers profound changes. This relevant issue shows that public policies to preserve natural landscape untouched as possible are far from unanimous, as most respondents did not state clearly or still see minimal changes in the natural landscape. Certain main natural spots suffered requalification to discipline tourists passing through, improving security, comfort, and logistics. However, how invasive the requalification becomes and to what extent retaining natural places should be a matter for analysis from the tourists' point of view [50] is the critical question.

Since 2015, the tourism sector has become the second most significant in the Azores' fragile economy. Responsible for low unemployment and moderate-income growth [68], tourism in the Azores relies on a tight connection with nature. Public policies to promote accommodation without collateral harm to the natural environment are a real challenge in the Azores. It is not surprising that in the Azores context, both come as the most affected by public and territorial policies.

Through cluster analysis it is made clear that two factors rule public policies on growth and development of the Azores: (i) impact on the natural landscape and (ii) suitable production factors. 
For example, this concerns the case of service positioning, type of investment projects, and their sustainability and labor conditions.

This article focuses on spatial planning, regional public policies, and their relationship with tourism activities for sustainable territorial development and growth on the Azores. Case study research methods, territorial impact analysis, and questionnaires to explore the public perception were used. Accommodation (54.7\%) and nature (51.9\%) were the most affected and cultural $(15.1 \%)$, and rental/hire services (17.9\%) were less affected by public territorial policies in the Azores. The impact on the natural landscape and suitable production factor are two factors that rule public policies.

In comparison with a study carried by Castanho et al. [30] in the insular region of Madeira, using the same methodology and a similar questionnaire, it is possible to realize that considering the public perceptions towards territorial management and regional public policies, the latter are much better conducted in Azores regions in the context of sustainability. It is curious to find differences between those two studies, as both insular territories are geographically nearby and also belong to the same sovereign country (Portugal); however, they have autonomous regional governments and, consequently, different policies and territorial management and governance.

Based on the questionnaire results, it seems the Azores' strategic planning has been conducted with great responsibility, and sustainability issues have been essential in this endeavor. We also believe that the need to protect the region's competitive advantages, such as natural assets and high levels of sustainability, has been pivotal to following a consistent planning model [17].

Besides, nature tourism, ecotourism, and adventure tourism, inspired by sustainability principles, can be critical elements in this model. Regional technical plans have chosen nature tourism as the priority product for the destination, in addition to reemphasizing the significance of sustainability for continuous improvement and valuation thereof [17]. Tourism is an important strategic sector for the Azores and can make a decisive enrichment to the region's development and growth [17].

Consequently, the following guidelines and principles should be considered in the pursuit of long-term regional sustainability regarding regional public policies and tourism in the Azores Islands:

- design policies that focus on sustainable development, endeavoring to create meaningful investments in infrastructure and services (mainly on accessibility by air);

- promote the conservation and preservation of ecological systems;

- encourage the interaction between societies and the environment;

- $\quad$ support entrepreneurship associated with small and medium-sized businesses (promoting the variety of offering);

- prioritize rural tourism over mass tourism.

Thereby, the authors believe that the Azores territorial management towards the so-desired sustainability should be used as a case study for similar territories.

This research contributes to moving further scientific knowledge on this topic which comes mainly from the insights for academics and practitioners. It should be a relevant guidance for the theoretical growth and development of economic models by decision makers.

\section{Study Limitations and Further Research}

Even if this study expands our knowledge and understanding regarding the relationship between territorial management and governance, regional public policies, and tourism, significant prospects of future research are still needed.

The territory is not a static entity; on the contrary, it presents much dynamism. In fact, these issues sometimes seem to evolve in insular territories even quicker, leading to uncertainty of the patterns and directions of their growth and their ensuing challenges. Therefore, the close monitoring process of the impact of such regional policies and territorial strategies of management over the tourism sector and sustainability a whole, along with the development of similar studies in other insular regions, is seen as essential to enriching this subject and expanding our knowledge on the topic. 
The research focuses only on the political-strategic field; however, for a full understanding of a process as complex as territorial governance and tourism, other themes and perspectives should be analyzed. For example, future research should focus on tourist opinion regarding the natural landscape to better appraise the direct impact of the introduced public policies.

Author Contributions: Conceptualization, R.A.C.; data curation, P.P. and Á.S.; formal analysis, Á.S.; funding acquisition, G.C.; investigation, R.A.C. and P.P.; methodology, Á.S.; project administration, G.C.; software, Á.S.; supervision, Á.S.; validation, G.C.; visualization, C.B.C.; writing—original draft, R.A.C.; Writing—review \& editing, R.A.C., P.P. and C.B.C. All authors have read and agreed to the published version of the manuscript.

Funding: This paper is financed by Portuguese national funds through FCT-Fundação para a Ciência e a Tecnologia, I.P., project number UIDB/00685/2020 and also by the project GREAT-Genuine Rural Experiences in the Azores Tourism, with the code: ACORES-01-0145-FEDER-000089.

Conflicts of Interest: The authors declare no conflict of interest.

\section{References}

1. Marchant, R.; Lane, P. Past perspectives for the future: Foundations for sustainable development in East Africa. J. Archaeol. Sci. 2014, 51, 12-21. [CrossRef]

2. Amado, M. Planeamento Urbano Sustentável; Caleidoscópio: Lisboa, Portugal, 2009; ISBN 9789728801748. (In Portuguese)

3. Lippolis, L. Viaggio al Termine Della Cità—La Metropoli e le Arti Nell'Áutumno PostModerno (1972-2001); Eleuthera: Genova, Italia, 2016.

4. Santos, R. O Regresso dos Emigrantes Portugueses e o Desenvolvimento do Turismo em Portugal. Ph.D. Thesis, University of Aveiro, Aveiro, Portugal, 2013.

5. Naranjo Gómez, J.M.; Lousada, S.; Velarde, J.G.; Castanho, R.A.; Loures, L. Land-use changes in the canary archipelago using the CORINE data: A retrospective analysis. Land 2020, 9, 232. [CrossRef]

6. Spangenberg, J. Towards Sustainable Europe, A Study from the Wuppertal Institute for Friends of the Earth Europe; Russel Press: Luton, UK, 1995.

7. Vulevic, A.; Macura, D.; Djordjevic, D.; Castanho, R. Assessing Accessibility and Transport Infrastructure Inequities in Administrative Units in Serbia's Danube Corridor Based on Multi-Criteria Analysis and GIS Mapping Tools; Transylvanian Review of Administrative Sciences; Babes-Bolyai University: Cluj-Napoca, Romania, 2018; Volume 53, pp. 123-142. [CrossRef]

8. Fadigas, L. Urbanismo e Território, As Politicas Públicas; Edições Sílabo: Lisbon, Portugal, 2015. (In Portuguese)

9. Loures, L.; Panagopoulos, T. Reclamation of derelict industrial land in Portugal-greening is not enough. Int. J. Sustain. Dev. Plan. 2010, 5, 343-350. [CrossRef]

10. Loures, L. Post-industrial landscapes as drivers for urban redevelopment: Public versus expert perspectives towards the benefits and barriers of the reuse of post-industrial sites in urban areas. Habitat Int. 2015, 45, 72-81. [CrossRef]

11. Loures, L.; Naranjo Gómez, J.M.; Castanho, R.A.; Loures, A. Benefits and limitations of public involvement processes in landscape redevelopment projects-Learning from practice. In Regional Intelligence Spatial Analysis and Anthropogenic Regional Challenges in the Digital Age; Springer: Cham, Switzerland, 2020; pp. 29-48.

12. Naranjo, J.M. Impacts on the social cohesion of mainland Spain's future motorway and high-speed rail networks. Sustainability 2016, 8, 624. [CrossRef]

13. Vulevic, A. Infrastructural Corridors and Their Influence on Spatial Development-Example of Corridor VII in Serbia. Ph.D. Thesis, Faculty of Geography, University of Belgrade, Belgrade, Serbia, 2013.

14. Santos, R.; Castanho, R.A.; Lousada, S. Return migration and tourism sustainability in portugal: Extracting opportunities for sustainable common planning in southern europe. Sustainability 2019, 11, 6468. [CrossRef]

15. Jurado Almonte, J.M.; Tristancho, A.F. Experiencias En Turismo Accesible En Andalucía Y Portugal: Especial Atención Al Ámbito Alentejo-Algarve-Provincia De Huelva; Servicio de Publicaciones de la Universidad de Huelva: Huelva, Spain, 2016; Volume 182.

16. Santos, C.; Couto, G.; Pimentel, P.; Vieira, J. Quality of the Azores destination in the perspective of tourists. Tour. Hosp. Res. 2011, 12, 32-42. [CrossRef] 
17. Castanho, R.A.; Couto, G.; Pimentel, P.M. Principles of sustainable tourism and cultural management in rural and ultra-peripheral territories: Extracting guidelines for its application in the Azores Archipelago. Cult. Manag. Sci. Educ. 2020, 4. [CrossRef]

18. Antrop, M. Sustainable landscapes: Contradiction, fiction or utopia? Landsc. Urban Plan. 2006, 75, $187-197$. [CrossRef]

19. Loures, L.; Castanho, R.A.; Vulevic, A.; Naranjo Gómez, J.; Cabezas, J.; Fernández-Pozo, L. The multi-variated effect of city cooperation in land use planning and decision-making processes-a european analysis. In Urban Agglomerations; InTech: Vienna, Austria, 2018; pp. 87-106. ISBN 978-953-51-5884-4.

20. Magalhães, M. A Arquitectura Paisagista: Morfologia e Complexidade; Editorial Estampa: Lisboa, Portugal, 2001.

21. Vargues, P.; Loures, L. Using geographic information systems in visual and aesthetic analsis: The case study of a golf course in Algarve. WSEAS Trans. Environ. Dev. 2008, 4, 774-783.

22. Bilgili, F.; Ulucak, R.; Koçak, E.; İlkay, S. Does globalization matter for environmental sustainability? Empirical investigation for Turkey by Markov regime switching models. Environ. Sci. Pollut. Res. 2020, 27, 1087-1100. [CrossRef] [PubMed]

23. Faludi, A.; Valk, A. Rule and order dutch planning doctrine in the twentieth century. In The GeoJournal Library; Springer: Heidelberg, The Netherlands, 1994; Volume 28.

24. Beck, U. Risikogesellschaft-The Risk Society; BACHELOR MASTER: Frankfurt, Germany, 1988.

25. Spangenberg, J. Sustainable Development-Concepts and Indicators; Russel Press: Koln, Germany, 2000.

26. Naranjo Gómez, J.M.; Loures, L.; Castanho, R.A.; Cabezas, J.; Fernández-Pozo, L.; Lousada, S.; Escórcio, P. Assessing Land Use Changes in European Territories: A Retrospective Study from 1990 to 2012; IntechOpen: London, UK, 2018.

27. Codosero Rodas, J.; Cabezas, J.; Naranjo Gómez, J.; Castanho, R.A. Risk premium assessment for the sustainable valuation of urban development land: Evidence from Spain. Sustainability 2019, 11, 4191. [CrossRef]

28. Codosero Rodas, J.; Castanho, R.A.; Cabezas, J.; Naranjo Gómez, J. Sustainable valuation of land for development, Adding value with urban planning progress, A Spanish case study. Land Use Policy 2020, 92, 104456. [CrossRef]

29. European Union (EU). Policy Forum on Development, Working Group: Social Pillar of Sustainable Development. Available online: www.europa.eu (accessed on 11 July 2020).

30. Yigitcanlar, T.; Dur, F.; Dizdarogluc, D. Towards prosperous sustainable cities: A multiscalar urban sustainability assessment approach. Habitat Int. 2015, 45, 36-46. [CrossRef]

31. Kaletová, T.; Loures, L.; Castanho, R.A.; Aydin, E.; Gama, J.; Loures, A.; Truchy, A. Relevance of Intermittent Rivers and Streams in Agricultural Landscape and Their Impact on Provided Ecosystem Services-A Mediterranean Case Study. Int. J. Environ. Res. Public Health 2019, 16, 2693. [CrossRef]

32. Hui, E.; Bao, H. The logic behind conflicts in land acquisition in contemporary China: A framework based upon game theory. Land Use Policy 2013, 30, 373-380. [CrossRef]

33. Huntington, S.P. The Clash of Civilizations and the Remaking of World Order; Penguin Books: Haryana, India, 1996.

34. Yu, A.T.W.; Wu, Y.; Shen, J.; Zhang, X.; Shen, L.; Shan, L. The key causes of urban-rural conflict in China. Habitat Int. 2015, 49, 65-73. [CrossRef]

35. Morais, J.; Castanho, R.A.; Loures, L.; Pinto-Gomes, C.; Santos, P. Villagers' Perceptions of Tourism Activities in Iona National Park: Locality as a Key Factor in Planning for Sustainability. Sustainability 2019, 11, 4448. [CrossRef]

36. Rodríguez-Serrano, I.; Caldés, N.; De La Rúa, C.; Lechón, Y.; Garrido, A. Using the Frame-work for Integrated Sustainability Assessment (FISA) to expand the Multiregional Input-Output analysis to account for the three pillars of sustainability. Environ. Dev. Sustain. 2017, 19, 1981-1997. [CrossRef]

37. Fadahunsi, J.T. Application of geographical information system (GIS) technology to tourism management in ile-ife, osun state, nigeria. Pac. J. Sci. Technol. 2011, 12, 274-283.

38. Labrianidis, L.; Thanassis, K. A Suggested Typology of Rural Areas in Europe. Available online: Cordis. europa.eu (accessed on 10 July 2020).

39. Sharpley, R.; Vass, A. Tourism, farming and diversification: An attitudinal study. Tour. Manag. 2006, 27, 1040-1052. [CrossRef]

40. Williams, A. Introduction. In Southern Europe Transformed-Political and Economic Change in Greece, Italy, Portugal and Spain; Williams, A., Ed.; Harper and Row: New York, NY, USA, 1984. 
41. Fleischer, A.; Felsenstein, D. Support for rural tourism-Does it make a difference? Ann. Tour. Res. 2000, 27, 1007-1024. [CrossRef]

42. Mazumder, H.; Ahmed, M.; Al-Amin, Q. Estimating total contribution of tourism to Malaysia economy. Int. J. Bus. Manag. Soc. Sci. 2009, 2, 146-159.

43. Reeder, R.; Brown, D. Recreation, Tourism, and Rural Well-Being, Economic Research Report, Number 7; United States Department of Agriculture: Washington, DC, USA, 2005.

44. Castanho, R.A.; Behradfar, A.; Vulevic, A.; Naranjo Gómez, J. Analyzing Transportation Sustainability in the Canary Islands Archipelago. Infrastructures 2020, 5, 58. [CrossRef]

45. Vulevic, A.; Castanho, R.A.; Naranjo Gómez, J.M.; Loures, L.; Cabezas, J.; Fernández-Pozo, L.; Martín Gallardo, J. Accessibility Dynamics and Regional Cross-Border Cooperation (CBC) Perspectives in the Portuguese-Spanish Borderland. Sustainability 2020, 12, 1978. [CrossRef]

46. Kilkenny, M.; Partridge, M. Export Sectors and Rural Development. Am. J. Agric. Econ. 2009, 91, 910-929. [CrossRef]

47. Mahony, K.; Zyl, J. The impacts of tourism investment on rural communities: Three case studies in South Africa. Dev. S. Afr. 2002, 19, 83-103. [CrossRef]

48. Decreto Legislativo Regional, n. ${ }^{\circ}$ 38/2008/A. Available online: https://dre.pt/application/conteudo/455635 (accessed on 24 July 2020).

49. Silva, F.; Almeida, M. Sustentabilidade do turismo na natureza nos Açores-O caso do canyoning. In Turismo e Desporto Na Natureza; do Céu Almeida, M., Ed.; Associação de Desportos de Aventura Desnível: Estoril, Portugal, 2013; pp. 5-19.

50. Vieira, J.; Couto, G.; Pimentel, P.; Menezes, A.; Moniz, A.; Sousa, F. The Satisfaction of the Nordic Tourist with the Azores as a Destination. Scand. J. Hosp. Tour. 2013, 13, 59-73. [CrossRef]

51. Varley, P.; Semple, T. Nordic Slow Adventure: Explorations in Time and Nature. Scand. J. Hosp. Tour. 2015, 15, 73-90. [CrossRef]

52. Varley, P.; Farkic, J.; Carnicelli, S. Hospitality in Wild Places. Hosp. Soc. 2018, 8, 137-157. [CrossRef]

53. Couto, G.; Pimentel, P.; Ponte, J. Tourism development potential in an insular territory: The case of ribeira grande in the Azores. J. Tour. Res. Hosp. 2017, 6. [CrossRef]

54. Couto, G.; Ponte, J.; Pimentel, P.; Sousa, Á.; Oliveira, A. Tourist satisfaction with the Municipality of Ponta Delgada (Azores). Rev. de Gestão e Secr. 2019, 10, 192-217. [CrossRef]

55. Ponte, J.; Couto, G.; Pimentel, P.; Santos, C.; Oliveira, A. Tourism activities and companies in a sustainable adventure tourism destination: The Azores; CEEAplA-Centro de Estudos de Economia Aplicada do Atlântico, Universidade dos Açores, Working Paper; CEEAplA: Ponta Delgada, Portugal, 2018.

56. Couto, G.; Ponte, J.; Pimentel, P.; Oliveira, A. Tourism activities and companies in a sustainable adventure tourism destination: The Azores. Tour. Manag. Stud. 2018, 14, 25-38. [CrossRef]

57. Couto, G.; Pimentel, P.; Ponte, J.; Gonçalves, P.; Duarte, D.; Arruda, A.; Oliveira, B.; Rodrigues, F. Açores Guia do Investidor para o Turismo Sustentável/Azores Investor's Guide to Sustainable Tourism; Fundação Luso-Americana para o Desenvolvimento (FLAD): Lisboa, Portugal, 2018; ISBN 978-972-8654-61-0.

58. UNWTO. AM Reports, Volume Nine-Global Report on Adventure Tourism; UNWTO: Madrid, Spain, 2014; Available online: https://bit.ly/2HxnY3z (accessed on 25 June 2020).

59. Yin, R. Case Study Research Design and Methods, 5th ed.; Sage: Thousand Oaks, CA, USA, 2014; ISBN 978-1-4522-4256-9.

60. Francis, M. A Case Study Method for Landscape Architecture; Urban Land Institute, University of California: Davis, CA, USA, 1998.

61. Castanho, R.A.; Lousada, S.; Camacho, R.; Naranjo Gómez, J.; Loures, L.; Cabezas, J. Ordenamento territorial e a sua relação com o turismo regional: O Caso de Estudo da Região Autónoma da Madeira (RAM). CIDADES Comunidades e Territ. 2018, 42-55. [CrossRef]

62. Bacelar-Nicolau, H. On the distribution equivalence in cluster analysis. In Pattern Recognition Theory and Applications, NATO ASI Series, Series F: Computer and Systems Sciences; Devijver, P.A., Kittler, J., Eds.; Springer: New York, NY, USA, 1987; pp. 73-79.

63. Lerman, I.C. Classification et Analyse Ordinale des Données; Dunod: Paris, France, 1981.

64. Lerman, I.C. Foundations and methods in combinatorial and statistical data analysis and clustering. In Series: Advanced Information and Knowledge Processing; Springer: London, UK, 2016. 
65. Bacelar-Nicolau, H. Two probabilistic models for classification of variables in frequency tables. In Classification and Related Methods of Data Analysis; Bock, H.-H., Ed.; Elsevier Sciences Publishers B.V.: North-Holland, The Netherlands, 1988; pp. 181-186.

66. Nicolau, F.C.; Bacelar-Nicolau, H. Some trends in the classification of variables. In Data Science, Classification, and Related Methods; Hayashi, C., Ohsumi, N., Yajima, K., Tanaca, Y., Bock, H.-H., Baba, Y., Eds.; Springer: Cham, Switzerland, 1998; pp. 89-98.

67. Couto, G.; Pimentel, P.; Ponte, J. Estratégia de Desenvolvimento Turístico da Ribeira Grande; Universidade dos Açores/Centro de Estudos de Economia Aplicada do Atlântico-CEEAplA: Ponta Delgada, Portugal, 2017; ISBN 978-989-8870-05-6.

68. Couto, G.; Pimentel, P.; Santos, C.; Ponte, J.; Oliveira, A. Estratégia de Desenvolvimento Turístico de Ponta Delgada; Universidade dos Açores/Centro de Estudos de Economia Aplicada do Atlântico-CEEAplA: Ponta Delgada, Portugal, 2017; ISBN 978-989-8870-08-7.

69. Couto, G.; Pimentel, P.; Ponte, J.; Gonçalves, P.; Duarte, D.; Arruda, A.; Oliveira, B. Açores na Europa-Impacto dos Fundos Estruturais; Edição Fundação Luso-Americana para o Desenvolvimento (FLAD): Lisboa, Portugal, 2017; ISBN 978-972-8654-60-3.

(C) 2020 by the authors. Licensee MDPI, Basel, Switzerland. This article is an open access article distributed under the terms and conditions of the Creative Commons Attribution (CC BY) license (http://creativecommons.org/licenses/by/4.0/). 